parents' attitudes towards their children's social and educational handicap. The survey stresses that parents need guidance and support in helping them to accept that their child may not make normal progress without special assistance.

\section{Water Development}

Is its annual report, whose principal conclusion is that Britain has too much water-not too little the Water Resources Board gives details of some intcresting research being carried out under its aegis. There has, for example, becn a programme of research into the regulation of the river Dee. Work on the generation of synthetic river flow data has been in progress at the Water Research Association and Lancaster University, and mathematical models representing catchment response are being studied at Imperial College. At the same time, attention is being paid to the problems of fisheries in the river, and it is hoped to build a fish counting station with an experimental electric fish barrier.

Less progress has been made in investigations of artificial recharge as a means of augmenting resources, largely owing to lack of staff. The report suggests that, although desalination plants similar to those built and projected in the United States will not bc profitable in Britain in the immediate future, there is sense in the use of flash distillation plants in conjunction with conventional surface reservoirs to meet intermit. tent excess demands. It is important, therefore, that operating experience of a multi-stage flash distillation plant should be obtained in Britain. The pilot electrodialysis plant in Essex for desalting brackish ground water from the chalk is now in operation, however, and there is a possibility that such a system could be used for reclamation of water from industrial and sewage effluents.

A most important part of the Water Resources Board's programme is the development of automatic hydrometric instrumentation. It is hoped that by mid-1968 equipment will be available for recording climatological and river water quality data on magnetic tape in such a way that the information can easily be fed into a computer. The board has negotiated with instrument manufacturers as a group, rather than individually, and feels sure that the advantages of this particular procedure have been significant. An ICT $190 \mathrm{l}(\mathrm{S})$ computer has very recently been acquired, and a team of staff to handle it recruited. The new com. puter section will serve all the divisions of the board. At present river flow data have been processed for river authorities, and the new computer will allow the service to be extended to cover climatic and other data.

The total expenditure of the board on research and on contributions for the support of university and river authority work was $£ 212,500$ last year.

\section{Production in Japan}

JAPAN is expected to overtake West Germany in the production of motor vehicles this year, and so become the second largest motor manufacturer in the world. More than three million cars will have been built, an increase of no less than 40 per cent since 1966 . Nor will this rate of growth fall, for production in 1968 should easily exceed four million vehicles.

Japanese exports used to be thought of as imitative and voluminous. Japan's achievements in shipbuilding and light engineering have convinced. Westerners that the first of these epithets is unjustified, but it would surprise many to know that Japan's exports in 1966 were little more than half those of Britain- $\$ 8,450 \mathrm{~m}$ against $\$ 14,000 \mathrm{~m}$, at the old rate of exchange. But if those in the West have exaggerated Japan's export performance, they have paid little attention to her importance as a producer of goods, as the table shows.

W. Ger-

Japan many Britain Erance Italy

Sulphuric acid

Synthetic

fibres

Steel

Motor

vehicles

Electricity

TV sets

Ships

\begin{tabular}{|c|c|c|c|c|}
\hline $5 \cdot 66$ & $3 \cdot 06$ & $3 \cdot 3$ & $2 \cdot 9$ & 4.75 million tons \\
\hline $\begin{array}{r}1,098 \\
41\end{array}$ & $\begin{array}{r}I, 025 \\
36\end{array}$ & $\begin{array}{r}846 \\
27\end{array}$ & $\begin{array}{r}475 \\
19\end{array}$ & $\begin{array}{l}650 \text { million } 1 b . \\
12 \cdot 6 \text { million tons }\end{array}$ \\
\hline $\begin{array}{r}1 \cdot 88 \\
180\end{array}$ & $\begin{array}{l}2 \cdot 9 \\
172\end{array}$ & $\begin{array}{l}2 \cdot 2 \\
148\end{array}$ & $\begin{array}{l}1 \cdot 5 \\
101\end{array}$ & $\begin{array}{l}11.4 \text { million } \\
82 \text { thousand million } \\
\text { units }\end{array}$ \\
\hline $\begin{array}{l}4 \cdot 2 \\
5 \cdot 4\end{array}$ & $\begin{array}{l}2 \cdot 8 \\
1 \cdot 02\end{array}$ & $\begin{array}{l}1 \cdot 6 \\
1.07\end{array}$ & $\begin{array}{l}1 \cdot 25 \\
0.48\end{array}$ & $\begin{array}{l}1.2 \text { million } \\
0.44 \text { xnillion tons } \\
\text { launched }\end{array}$ \\
\hline
\end{tabular}

Statistics of Industrial Production, 1965.

The foregoing table demonstrates the somewhat surprising fact that even in 1965, Japan was producing more steel, electricity, television sets, and, of course, ships than France and Italy combined, and that her output of synthetic fibres and motor vehicles was even then comparable with the combined totals of those two countries. It is interesting to reflect on the difference between the economic and political weights of the first four countries listed here. Japan's reliance on the United States as a trading partner precludes extravagant political gestures. Perhaps the next few years will see Japan rise to a diplomatic importance commensurate with her strength.

\section{Pooling Ocean Resources}

TwENTY-EIGHT nations have joined in a proposal to set up a United Nations committee to study the peaceful international exploitation of the ocean floors of the world: the United States is a sponsor of the proposal.

According to a draft resolution presented to the General Assembly's main political committee, the proposed committee will be required to conduct a survey of the past and present activities of the United Nations and its various agencies regarding the ocean floor and of existing international agreements concerning them; to summarize the scientific, economic, technical, legal and other problems which are involved in intcrnational use of underwater resources; and, finally, to suggest the practical means by which international co-operation could be promoted in the explora. tion, conservation and use of the ocean floor and its sub-soil.

The recommendation grew out of a debate on the subject in the political committee, and it was Malta which suggested that resources beneath the sea should be exploited for the benefit of all mankind. In deference to national claims of territorial watcrs, the draft resolution restricts its recommendations to the "sea bed and the ocean floor, and the sub-soil thereof, underlying the high seas beyond the limits of present national jurisdiction". Before the new committee can be set up, however, the draft resolution must 
first be endorsed by the political committee and then by the General Assembly as a whole.

\section{Marketing is King}

THE British engineering industry must give greater attention to marketing. This was the message delivered by the managing director of Massey Ferguson (UK), Mr J. W. Beith, in his lecture last week to the Institute of Mechanical Engineers.

Of the 14,992 engineering establishments in Britain, six hundred, or 4 per cent, account for two-thirds of the industry's total exports. An NEDC report in 1965 indicated that the probable rate of return on new investments in the engineering industry has been between 6 and 8 per cent during a period when the acceptable break-even rate was regarded as 15 per cent. Figures such as these, and the high import levels of foreign machine tools, indicate that some manufacturers fail to exploit in the market place the undoubted technical expertise which they possess.

Marketing, Mr Beith declared, should be the paramount activity in a company's operations, and must antedate and determine even the discovery in the research laboratories. If a product is to be tailored to its market, the whole strategy of a firm must be oriented towards the complex of research and planning activities which constitute marketing. Market research includes studies of such factors as the political and economic influences on a market, the demographic trends, the distribution of incomes and expenditures, and the likely appeal of alternative products. These findings form the basis for market planning, the function of which is to specify the product which will most profitably meet the situation described by market research. Market planning defines the physical characteristics of the product, its price, utility and styling; only then can design and manufacture begin, and any afterthoughts will be increasingly expensive. The goal of market planning is to strike the best balance between minimizing unit production costs and maximizing market appeal.

"The future of large sectors of engineering production," Mr Beith said, "will be influenced by the impact of marketing on engineering firms, and by the changes which it will bring about within those firms." The increasing importance of marketing is likely to favour the large firm against the small and to lead to fewer and larger firms. But perhaps the greatest change as firms become more market oriented, Mr Beith suggests, is that engineers will be expected to work within the parameters of the marketing approach and to think in terms not of the product itself but of its marketability.

\section{Parliament in Britain}

\section{Nuclear Power}

AskeD what effect the proposed reductions in capital spending by the nationalized industries would have on the construction of nuclear power stations, Mr Richard Marsh, the Minister of Power, replied that the start of one power station would probably be deferred. (Written answer, December 18.) At question time on the following day, $\mathrm{Mr}$ Wedgwood Benn, the Minister of Technology, defended his decision to close the Culham Establishment, set up for research into the generation of electricity by means of fusion. He said that that programme was well over the horizon, perhaps as much as 25 years ahead. As for the proposal, put to him by Mr David Price, that he transfer Culham from the Atomic Energy Authority to the Science Research Council, he said that work on astrophysics at Culham was to be undertaken by the SRC, and that he was taking Mr Price's proposals seriously.

\section{Sonic Booms}

THE subject of sonic booms came up in both written and oral questions on December 19. The Minister of State for the Ministry of Technology, Mr Stonehouse, said that no decision had been made about restrictions to be placed on the speed of the Concorde airliner over inhabited areas. He estimated that the total market for the aircraft would be reduced to 65 per cent if a ban were to be imposed on the making of supersonic booms overland. Mr Stonehouse went on to say that he did not think it would be wise to start international discussions on supersonic flight over land. Britain, he said, was in touch with France and the United States and would co-ordinate with them in any decision. Nobody could be certain about the characteristics of the bang from Concorde until the aircraft was flying, but there was a great deal that could be learned, and was being learned, from the intensive tests carried out in the United States. In written replies to questions put to him by members, Mr Stonehouse said that the Ministry of Technology would shortly issue a statement about the July sonic boom tests. Thirteen local authorities had commented on various aspects of these tests.

\section{American Aircraft Imports}

IN a written answer, Mr Stonehouse gave figures for the trade in aircraft and space products between Britain and the United States in the first ten months of this year. Britain imported $£ 64,541,000$ worth of aircraft, exporting $£ 37,645,000$ worth to the US. Mr Stonehouse thought that the export prospects of the aircraft industry would be enhanced as a result of devaluation. A Procurement Committee had been established under the British National Export Council and the Confederation of British Industries with the object of securing orders within the aerospace and avionics fields. (Written answer, December 20.)

\section{Civil Defence Warning System}

Lord Stonham, Minister of State, Home Office, in a debate in the House of Lords, gave details of the warning system which would be used to alert the civil population in the event of war. He claimed that the warning system was virtually instantaneous and nation-wide. There were two types of warning signal. The first was a siren similar to that used in the last war. The difference was that the system would now be operated centrally, and warning would be communicated within 30 seconds to 22,000 different points. Each warning point was equipped with a radiac survey meter and, in the event of a breakdown in the communication system, the warning point operator would sound a warning when fall-out registered on the survey meter reached $0 \cdot 3$ röntgens per hour. Warning of the actual fall-out would be sounded by maroon. Distribution of maroons would begin early next year. In addition, fall-out warnings would be given by the BBC's wartime broadcasting system, picked up by transistor radios. (Debate, eivil defence warnings, December 19.) 